\title{
Description of novel microsatellite loci in the Neotropical fish Prochilodus argenteus and cross-amplification in $P$. costatus and $P$. lineatus
}

\author{
Anna C.D.R. Barbosa, Felipe Galzerani, Thaís C. Corrêa, Pedro M. Galetti Jr. and Terumi Hatanaka \\ Universidade Federal de São Carlos, Departamento de Genética e Evolução, São Carlos, SP, Brazil.
}

\begin{abstract}
Prochilodus is one of the most important fish resources of South America, in addition to the important role it plays in nutrient cycling of Neotropical rivers. In the present study, we describe the isolation and characterization of nine novel microsatellite loci in Prochilodus argenteus. The number of alleles per polymorphic locus varied from 5 (Par76) to 21 (Par85), revealing a total of 116 alleles. The values of observed and expected heterozygosities ranged from 0.629 (Par69) to 0.926 (Par85 and Par86) and from 0.643 (Par66) to 0.931 (Par80), respectively. Furthermore, the ability of these and other previously described microsatellite markers to amplify orthologous loci was tested in two related species, Prochilodus costatus and Prochilodus lineatus. These loci will be useful for studies of population genetic structure in this group of fishes, and in aiding future genetic mapping studies of $P$. argenteus.
\end{abstract}

Key words: cross-species amplification, enrichment libraries, microsatellite, Prochilodus.

Received: August 21, 2006; Accepted: March 13, 2007.

Family Prochilodontidae constitutes one of the most important fish resources of South America (Bayley and Petrere, 1989), in addition to its important role in nutrient cycling in Neotropical rivers (Flecker, 1996). Prochilodus comprises 49 nominal species of which only 13 species are valid (Castro and Vari, 2003). Among the species found in the São Francisco River basin, Prochilodus argenteus, popularly known as curimatã-pacu, forms a bulk of the subsistence fishery of the region, although numbers harvested have drastically declined in the last years (Sato and Godinho, 2004).

Microsatellites are polymorphic DNA sequences containing short tandemly arranged repetitions (Tautz, 1989), distributed throughout the genome (Litt and Luty, 1989), and found in all prokaryotic and eukaryotic genomes studied until now (Zane et al., 2002). Due to their high variability, these genetic markers have been widely used in genetic mapping (Knapik et al., 1998; Shimoda et al., 1999; Coimbra et al., 2003) and population structure studies (Hatanaka et al., 2006; Primmer et al., 2006). However, one of the great impediments for the wider use of microsatellites is the need to isolate and characterize these markers via cloning and sequencing of genomic libraries for each species of interest (Angers and Bernatchez, 1997). Nevertheless, once the flanking sequences of microsatellite markers are

Send correspondence to T. Hatanaka. Universidade Federal de São Carlos, Departamento de Genética e Evolução, Rodovia Washington Luís km 235, 13565-905 São Carlos, SP, Brazil. E-mail: terumiha@terra.com.br. known, a large number of individuals may be rapidly genotyped.

Although the Neotropical ichthyofauna is the world's most diversified (Lowe-McConnel,1969; 1987), microsatellite primers have been published only for Piaractus mesopotamicus (Calcagnotto et al., 2001), Astyanax fasciatus (Strecker, 2003), Arapaima gigas (Farias et al., 2003), Brycon opalinus (Barroso et al., 2003), Eigenmannia sp. (Moysés et al., 2005), Pseudoplatystoma corruscans (Revaldaves et al., 2005), Brycon hilarii (Sanches and Galetti, 2006) and Prochilodus costatus (Carvalho-Costa et al., 2006). The isolation and characterization of microsatellite loci has also been performed in $P$. argenteus, and thirteen loci were previously described for this species (Barbosa et al., 2006). However, for the construction of genetic maps, a large number of genetic markers is necessary. Thus, the present study had the objective of describing novel $P$. argenteus loci in order to aid future genetic mapping studies. Furthermore, the heterologous amplification of these and other previously described loci was tested in two other Prochilodus species, specifically $P$. costatus and P. lineatus.

Total genomic DNA was extracted from liver tissue of a $P$. argenteus individual using the phenol-chloroform method (Sambrook et al., 1989). A partial genomic library enriched for tetranucleotide loci was constructed following the protocols of Hamilton et al. (1999). The DNA was digested with $B s t U$ I and DNA fragments ranging from 300 to $1200 \mathrm{bp}$ were excised from the gel and purified using the 
Wizard SV Gel and PCR Clean-Up System kit (Promega). Enrichment was performed using eight biotinylated oligonucleotides $\quad\left\{(\mathrm{AAAC})_{6} \quad(\mathrm{AAAG})_{6} \quad(\mathrm{AATC})_{6} \quad(\mathrm{AATG})_{6}\right.$ $\left.(\mathrm{ACCT})_{6}(\mathrm{ACAG})_{6}(\mathrm{ACTC})_{6}(\mathrm{ACTG})_{6}\right\}$ and streptavidincoated magnetic beads (Streptavidin Magnesphere Paramagnetic Particles, Promega). Clones containing inserts were sequenced using the DYEnamic ET Terminator Cycle Sequencing kit (GE Healthcare) and products were resolved on an ABI Prism 377 automated sequencer (Applied Biosystems). The microsatellite-like sequences were analyzed using Tandem Repeats Finder (Benson, 1999) and flanking primers were then designed using the Primer 3 software (Rozen and Skaletsky, 2000).

To analyze if loci were variable up to 30 individuals from two collection sites in the São Francisco River (Brazil) were used. All loci were amplified following the PCR method described by Schuelke (2000), in which three primers are used simultaneously, a fluorescently-marked M13 primer, a forward primer with a fusion of a leading M13 universal sequence, and a reverse primer. PCR reactions were carried out in $10 \mu \mathrm{L}$ reactions containing $100 \mathrm{ng}$ of DNA, $200 \mu \mathrm{M}$ dNTPs, PCR buffer $(20 \mathrm{mM}$ Tris-HCl, pH 8.4, and $50 \mathrm{mM} \mathrm{KCl}$; LGC Biotecnologia), 4 pmol of each reverse and 6-FAM or NED M13 (-21) primers and 1 pmol of the forward primer, $1.5 \mathrm{mM} \mathrm{MgCl}_{2}$ and $1 \mathrm{U}$ of Taq DNA Polymerase (LGC Biotecnologia). Conditions of the PCR amplification were as follows: 1 cycle at $95^{\circ} \mathrm{C}(5 \mathrm{~min}), 35$ cycles at $94{ }^{\circ} \mathrm{C}(30 \mathrm{~s}), 30 \mathrm{~s}$ at the annealing temperature (Table 1) and $72{ }^{\circ} \mathrm{C}(30 \mathrm{~s})$, followed by 8 cycles $94{ }^{\circ} \mathrm{C}$ $(30 \mathrm{~s}), 53{ }^{\circ} \mathrm{C}(45 \mathrm{~s}), 72{ }^{\circ} \mathrm{C}(45 \mathrm{~s})$, and a final extension at $72{ }^{\circ} \mathrm{C}$ for $10 \mathrm{~min}$.
For genotyping, the PCR products were subjected to electrophoresis along with GeneScan ROX 350 (Applied Biosystems) internal size standards on an ABI 377 automated sequencer (Applied Biosystems). Allele sizes were assigned using the Genescan and Genotyper 2.5 software packages (Applied Biosystems). Hardy-Weinberg equilibrium (HWE), observed and expected heterozygosities and linkage disequilibrium tests were performed using the software Genepop 3.3 (Raymond and Rousset, 1995).

Of the 96 sequenced clones, 51 (53.13\%) contained microsatellite sequences and primers were designed for 31 loci (Par 55 - Par86). Of these, 15 were successfully amplified. Only loci Par61, Par72, Par73 and Par74 presented a monomorphic pattern, i.e. the most common alleles presented a frequency superior to $95 \%$ (Zou et al., 2005), whereas the others showed high levels of polymorphism. The number of alleles per polymorphic locus varied from 5 (Par76) to 21 (Par85), revealing a total of 116 alleles. The values of observed and expected heterozygosities ranged from 0.629 (Par69) to 0.926 (Par85 and Par86) and from 0.643 (Par66) to 0.931 (Par80), respectively. Significant deviations from the Hardy-Weinberg equilibrium were found in the Par71, Par83 and Par86 loci $(\mathrm{p}<0.05)$, which may be explained by the presence of null alleles, mating systems, cryptic population structure and non-random sampling. Summary data for all loci are presented in Table 1.

To test cross-species amplification, three individuals of $P$. costatus and three individuals of $P$. lineatus were used. In addition to the loci isolated in the present study, 13 previously described loci for $P$. argenteus (Barbosa et al., 2006) were also amplified in these species. The markers de-

Table 1 - Characterization of microsatellite loci in Prochilodus argenteus.

\begin{tabular}{|c|c|c|c|c|c|c|c|c|}
\hline $\begin{array}{l}\text { Locus GenBank } \\
\text { accession } n \text {. }\end{array}$ & Repeat motif & Primers $\left(5^{\prime} \rightarrow 3^{\prime}\right)$ & $\mathrm{Ta}\left({ }^{\circ} \mathrm{C}\right)$ & $\begin{array}{l}\text { Size-range } \\
(\mathrm{pb})\end{array}$ & $\mathrm{N}_{\mathrm{a}}$ & $H_{\mathrm{O}}$ & $H_{\mathrm{E}}$ & $\mathrm{p}$ \\
\hline $\begin{array}{l}\text { Par66 } \\
\text { DQ524172 }\end{array}$ & $(\mathrm{AACA})_{12}$ & $\begin{array}{l}\text { F: TCTATAACTGTGGTCGTATG } \\
\text { R: GAGGTTTTGAGATCAGTTG }\end{array}$ & 47.0 & $153-185$ & 9 & 0.737 & 0.643 & 0.528 \\
\hline $\begin{array}{l}\text { Par69 } \\
\text { DQ524173 }\end{array}$ & $(\mathrm{TTAT})_{7}(\mathrm{TCAT})_{6}$ & $\begin{array}{l}\text { F: AATCTTTTCTAGGCTGTAGG } \\
\text { R: GGGAAGTAGAAAGAAGAAAC }\end{array}$ & 55.6 & $222-256$ & 7 & 0.629 & 0.700 & 0.969 \\
\hline $\begin{array}{l}\text { Par71 } \\
\text { DQ524174 }\end{array}$ & $(\mathrm{GA})_{24}$ & $\begin{array}{l}\text { F: TGTCGTCTGAAAGGAGTC } \\
\text { R: GAGGTTGTCCATTTTTAGAG }\end{array}$ & 55.6 & $237-281$ & 17 & 0.872 & 0.600 & $0.000 *$ \\
\hline $\begin{array}{l}\text { Par76 } \\
\text { DQ524175 }\end{array}$ & $(\mathrm{CAGT})_{16}$ & $\begin{array}{l}\text { F: GGGTTACATTACATTCTAGG } \\
\text { R: CAAGTCTCTTCTGCTAACTG }\end{array}$ & 53.4 & $226-242$ & 5 & 0.702 & 0.733 & 0.207 \\
\hline $\begin{array}{l}\text { Par80 } \\
\text { DQ524176 }\end{array}$ & $(\mathrm{CT})_{37}$ & $\begin{array}{l}\text { F: CTAACCTACAAACCTCATTC } \\
\text { R: CTGTAAAAGCTCCACTTATC }\end{array}$ & 51.3 & $221-279$ & 17 & 0.921 & 0.931 & 0.850 \\
\hline $\begin{array}{l}\text { Par82 } \\
\text { DQ524177 }\end{array}$ & $(\mathrm{CT})_{27}$ & $\begin{array}{l}\text { F: CTCTAACAAGGTGAAACAAC } \\
\text { R: TTTAAACTGTAGGCACAGAC }\end{array}$ & 51.3 & $177-209$ & 14 & 0.831 & 0.900 & 0.437 \\
\hline $\begin{array}{l}\text { Par83 } \\
\text { DQ524178 }\end{array}$ & $(\mathrm{CACT})_{11}$ & $\begin{array}{l}\text { F: CATTTTCTAACAGCACTCC } \\
\text { R: TTCTTGTTCTCCTGTGTAAC }\end{array}$ & 55.6 & $264-300$ & 10 & 0.853 & 0.897 & $0.043 *$ \\
\hline $\begin{array}{l}\text { Par85 } \\
\text { DQ524179 }\end{array}$ & $(\mathrm{AG})_{25}$ & $\begin{array}{l}\text { F: CCACTTAATGAGACCACAC } \\
\text { R: TTTCATTAGACTCGGTGAG }\end{array}$ & 51.3 & $227-271$ & 21 & 0.926 & 0.925 & 0.276 \\
\hline $\begin{array}{l}\text { Par86 } \\
\text { DQ524180 }\end{array}$ & $(\mathrm{GA})_{46}$ & $\begin{array}{l}\text { F: ATCCGTCTCTATGTGTGTC } \\
\text { R: TCTACAGTTACTTGGAGGAC }\end{array}$ & 57.8 & $135-181$ & 16 & 0.926 & 0.740 & $0.045^{*}$ \\
\hline
\end{tabular}

Ta, annealing temperature; bp, base pairs; $\mathrm{N}_{\mathrm{a}}$, total number of different alleles observed; $H_{\mathrm{O}}$, observed heterozygosity; $H_{\mathrm{E}}$, expected heterozygosity; HWE test, $\mathrm{p}$ values for Hardy-Weinberg equilibrium test; * $\mathrm{p}<0.05$. 
veloped for $P$. argenteus amplified and were polymorphic in both species tested. The efficiency of heterologous amplifications was $100 \%$ in $P$. costatus and $95.45 \%$ in $P$. lineatus (Par34 presented a faint band). Allele sizes for $P$. costatus and $P$. lineatus corresponded to the size range observed for $P$. argenteus. In P. costatus the loci Par34 and Par76 were monomorphic, while Par35, Par69, Par71, Par76 and Par82 were monomorphic in P. lineatus. All other remaining loci were polymorphic in their respective species (Table 2).

A description of these novel microsatellite loci in $P$. argenteus and the data showing their heterologous amplification in P. costatus and P. lineatus will provide useful markers that will allow a better understanding of the Prochilodus population structure, and will aid future $P$. argenteus genetic mapping studies.

\section{Acknowledgments}

We thank the Instituto Florestal de Minas Gerais for authorizing the capture of specimens. We are also very

Table 2 - Sample genotypes with allele sizes in base pairs.

\begin{tabular}{|c|c|c|c|c|c|c|}
\hline \multirow[b]{2}{*}{ Locus } & \multicolumn{3}{|c|}{ Prochilodus costatus } & \multicolumn{3}{|c|}{ Prochilodus lineatus } \\
\hline & 231 & 235 & 236 & 91 & 96 & 97 \\
\hline Par10* & $210 / 210$ & $182 / 194$ & $182 / 192$ & $192 / 200$ & $200 / 200$ & $200 / 200$ \\
\hline Par12* & $196 / 196$ & $196 / 220$ & $188 / 196$ & $232 / 232$ & $200 / 216$ & $200 / 216$ \\
\hline Par13* & $242 / 270$ & $250 / 260$ & $252 / 262$ & $258 / 264$ & $258 / 288$ & $256 / 262$ \\
\hline Par14* & $236 / 250$ & $220 / 250$ & $236 / 250$ & $208 / 220$ & $250 / 270$ & $250 / 270$ \\
\hline Par15* & $188 / 188$ & $168 / 178$ & $162 / 176$ & $154 / 182$ & $166 / 172$ & $150 / 170$ \\
\hline Par21* & $185 / 185$ & $173 / 185$ & $165 / 189$ & $173 / 185$ & $181 / 185$ & $181 / 185$ \\
\hline Par26* & $254 / 266$ & $302 / 302$ & $302 / 302$ & $302 / 302$ & $298 / 302$ & $298 / 302$ \\
\hline Par31* & $271 / 271$ & $269 / 271$ & $271 / 275$ & $273 / 275$ & $267 / 275$ & $271 / 271$ \\
\hline Par34* & $350 / 350$ & $350 / 350$ & $350 / 350$ & FB & FB & FB \\
\hline Par35* & $256 / 268$ & $256 / 256$ & $256 / 256$ & $256 / 256$ & $256 / 256$ & $256 / 256$ \\
\hline Par43* & $271 / 283$ & $257 / 265$ & $273 / 275$ & $251 / 255$ & $265 / 277$ & $247 / 247$ \\
\hline Par53* & $176 / 184$ & $176 / 188$ & $176 / 184$ & NP & $\mathrm{NP}$ & $188 / 188$ \\
\hline Par54* & $226 / 242$ & $222 / 222$ & $224 / 226$ & $224 / 230$ & $218 / 222$ & $224 / 226$ \\
\hline Par66 & $177 / 181$ & $177 / 185$ & $169 / 181$ & $177 / 181$ & $169 / 177$ & $169 / 177$ \\
\hline Par69 & $244 / 244$ & $236 / 244$ & $236 / 244$ & $252 / 252$ & $252 / 252$ & $252 / 252$ \\
\hline Par71 & $253 / 267$ & $269 / 275$ & $261 / 265$ & $275 / 275$ & $275 / 275$ & $275 / 275$ \\
\hline Par76 & $230 / 230$ & $230 / 230$ & $230 / 230$ & $230 / 230$ & $230 / 230$ & $230 / 230$ \\
\hline Par80 & $247 / 261$ & $227 / 237$ & $251 / 253$ & $219 / 225$ & $239 / 255$ & $239 / 257$ \\
\hline Par82 & $179 / 195$ & $191 / 193$ & $183 / 189$ & $195 / 195$ & $195 / 195$ & $195 / 195$ \\
\hline Par83 & $272 / 282$ & $264 / 272$ & $272 / 272$ & $276 / 280$ & $276 / 288$ & $276 / 288$ \\
\hline Par85 & $251 / 263$ & $243 / 257$ & $259 / 267$ & $243 / 243$ & $\mathrm{NP}$ & $225 / 237$ \\
\hline Par86 & $173 / 173$ & $189 / 189$ & $157 / 171$ & NP & $139 / 155$ & $139 / 155$ \\
\hline
\end{tabular}

$\mathrm{NP}=$ No $\mathrm{PCR}$ product, $\mathrm{FB}=$ Faint band, $*=$ Locus previously described in Barbosa et al. (2006). grateful to Dr. Yoshimi Sato and CEMIG-CODEVASF for collecting specimens and Prof. Dr. Flávio Henrique-Silva for allowing the use of the automated sequencer for genotyping. This research was supported by FAPESP (Fundação de Amparo à Pesquisa do Estado de São Paulo) and CNPq (Conselho Nacional de Desenvolvimento Científico e Tecnológico).

\section{References}

Angers B and Bernatchez L (1997) Complex evolution of a salmonid microsatellite locus and its consequences in inferring allelic divergence from size information. Mol Biol Evol 14:230-238.

Barbosa ACDR, Corrêa TC, Galzerani F, Galetti Jr PM and Hatanaka T (2006) Thirteen polymorphic microsatellite loci in the Neotropical fish Prochilodus argenteus (Characiformes, Prochilodontidae). Mol Ecol Notes 6:936938.

Barroso RM, Hilsdorf AWS, Moreira HLM, Mello AM, Guimarães EF, Cabello PH and Traub-Cseko YM (2003) Identification and characterization of microsatellites loci in Brycon opalinus (Cuvier, 1819) (Characiforme, Characidae, Bryconiae). Mol Ecol Notes 3:297-298.

Bayley PB and Petrere M (1989) Amazon fisheries: Assessment of methods, status, and management options. Canadian Sp Publ Fish Aquatic Sci 106:385-398.

Benson G (1999) Tandem repeats finder: A program to analyze DNA sequences. Nucleic Acids Res 27:573-580.

Calcagnotto D, Russello M and DeSalle R (2001) Isolation and characterization of microsatellite loci in Piaractus mesopotamicus and their applicability in other Serrasalminae fish. Mol Ecol Notes 1:245-247.

Carvalho-Costa LF, Hatanaka T and Galetti Jr PM (2006) Isolation and characterization of polymorphic microsatellite markers in the migratory fish Prochilodus costatus. Mol Ecol Notes 6:818-819.

Castro RMC and Vari RP (2003) Family Prochilodontidae. In: Reis RE, Kullander SO and Ferraris Jr CJ (eds) Check List of the Freshwaters of South and Central America. EDIPUCRS 1, Porto Alegre, pp 65-70.

Coimbra MRM, Kobayashi K, Koretsugu S, Hasegawa O, Ohara E, Ozaki A, Sakamoto T, Naruse K and Okamoto N (2003) A genetic linkage map of the Japanese flounder, Paralichthys olivaceus. Aquaculture 220:203-218.

Farias IP, Hrbek T, Brinkmann H, Sampaio I and Meyer A (2003) Characterization and isolation of DNA microsatellite primers for Arapaima gigas, an economically important but severely over-exploited fish species of the Amazon basin. Mol Ecol Notes 3:128-130.

Flecker AS (1996) Ecosystem engineering by a dominant detritivore in a diverse tropical stream. Ecology 77:1845-1854.

Hamilton MB, Pincus EL, Di Fiori A and Flesher RC (1999) Universal linker and ligation procedures for construction of genomic DNA libraries enriched for microsatellites. Biotechniques 27:500-507.

Hatanaka T, Henrique-Silva F and Galetti Jr PM (2006) Population substructuring in a migratory freshwater fish Prochilodus argenteus (Characiformes, Prochilodontidae) from the São Francisco River. Genetica 126:153-159. 
Knapik EW, Goodman A, Ekker M, Chevrette M, Delgado J, Neuhauss S, Shimoda N, Driever W, Fishman MC and Jacob HJ (1998) A microsatellite genetic linkage map for zebrafish (Danio rerio). Nat Genet 18:301-303.

Litt M and Luty JA (1989) A hypervariable microsatellite revelead by in vitro amplification of a dinucleotide repeat within the cardiac muscle actin gene. Am J Human Genet 44:397401.

Lowe-McConnel RH (1969) Speciation in tropical freshwater fishes. Biol J Linn Soc 1:51-75.

Lowe-McConnel RH (1987) Ecological studies on some lakes in the Amazon valley. Amazoniana 1:91-115.

Moysés CB, Mockford S, Almeida-Toledo LF and Wright JM (2005) Nine polymorphic microsatellite loci in the Neotropical electric eel Eigenmannia (Teleostei, Gymnotiformes). Mol Ecol Notes 5:7-9.

Primmer CR, Veselov AJ, Zubchenko A, Poututkin A, Bakhmet I and Koskinen MT (2006) Isolation by distance within a river system: Genetic population structuring of Atlantic salmon, Salmo salar, in tributaries of the Varzuga River in northwest Russia. Mol Ecol 15:653-666.

Raymond M and Rousset F (1995) Genepop: Population genetics software for exact tests and ecumenicism. J Hered 86:248249.

Revaldaves E, Pereira LHG, Foresti F and Oliveira C (2005) Isolation and characterization of microsatellite loci in Pseudoplatystoma corruscans (Siluriformes, Pimelodidae) and cross-species amplification. Mol Ecol Notes 5:464-465.

Rozen S and Skaletsky HJ (2000) Primer 3 on the www for general users and for biologist programmers. In: Krawetz $\mathrm{S}$ and
Misener S (eds) Bioinformatics Methods and Protocols: Methods in Molecular Biology. Human Press, Totowa, pp 365-386.

Sambrook J, Fritsch EF and Maniatis T (1989) Molecular Cloning: A Laboratory Manual. 2nd ed. Cold Spring Harbor Laboratory Press, New York.

Sanches A and Galetti Jr PM (2006) Microsatellites loci isolated in the freshwater fish Brycon hilarii. Mol Ecol Notes 6:1045-1046.

Sato Y and Godinho HP (2004) Migratory Fishes of the São Francisco River. In: Carolsfeld J, Harvey B, Ross C and Baer A (eds) Migratory Fishes of South America: Biology, Fisheries and Conservation Status. World Fisheries Trust, Victoria, $380 \mathrm{pp}$.

Schuelke M (2000) An economic method for the fluorescent labeling of PCR fragments. Nat Biotechnol 18:233-234.

Shimoda N, Knapik EW, Ziniti J, Sim C, Yamada E, Kaplan S, Jackson D, Sauvage F, Jacob H and Fishman M (1999) Zebrafish genetic map with 2000 microsatellites markers. Genomics 58:219-232.

Strecker U (2003) Polymorphic microsatellites isolated from the cave fish Astyanax fasciatus. Mol Ecol Notes 3:150-151.

Tautz D (1989) Hypervariability of simple sequences as a general source for polymorphic DNA markers. Nucleic Acid Res 17:6463-6471.

Zane L, Bargelloni L and Patarnello T (2002) Strategies for microsatellite isolation: A review. Mol Ecol 11:1-16.

Zou F, Yue B, Xu L and Zhang Y (2005) Isolation and characterization of microsatellite loci from forest musk deer (Moschus berezovskii). Zoolog Sci 22:593-598.

Associate Editor: Cláudio Oliveira 